\title{
INTEGRATED MANAGEMENT OF KARSTIC WATERS- A CASE STUDY OF THE ZLATIBOR MOUNTAIN MASSIF, SERBIA
}

\author{
MILENIC D. ${ }^{1}$ \\ MILANKOVIC Dj. ${ }^{1}$ \\ PETRIC M. ${ }^{2}$ \\ SAVIC N. ${ }^{1}$ \\ VRANJES A. ${ }^{1, *}$
}

\author{
${ }^{1}$ University of Belgrade, Faculty of Mining \& Geology \\ Dept. of Hydrogeology, Djusina 7, 11000 Belgrade, Serbia \\ ${ }^{2}$ Karst Research Institute at ZRC SAZU, \\ Titov trg 2, SI-6230 Postojna, Slovenia
}

Received: $15 / 03 / 2014$

Accepted: 23/05/2014

Available online: 12/09/2014 *to whom all correspondence should be addressed: e-mail: vranjes_ana@yahoo.ie

\section{ABSTRACT}

The Zlatibor mountain massif has significantly changed for the past 20 years due to the development of tourism, which has resulted in an increase in water consumption and environmental threats. This area abounds in considerable surface and groundwater resources, which are not utilised adequately. Surface water characterized by lower quality and unstable regimes was utilised for water supply, while groundwater with better qualitative properties was utilised in a small percentage. A number of significant and gradually developing problems are the direct consequence of this concept of water resource utilisation. So far, water supply of central settlements has been based on the concept of the utilisation of surface water from the Zlatibor reservoir which was built in the year 1972, nowadays being filled up above the designed level, while the centralized water supply of other settlements has not been adequately solved generally. Previous research has indicated that this area is characterized by karstic groundwater reserves of regional character, and in most cases they are not adequately utilised, which has opened the possibility of their proper utilisation and the change to a new concept of water management in the area of Zlatibor.

A new concept of water management implies the utilisation of karstic water, primarily, to resolve the public water supply issue. In the future, a number of benefits such as: resolving of centralized water supply issues, reduction of surface water pollution, creating opportunities for the utilisation of surface water for other purposes, creating new tourist zones, reduction of environmental pollution, improvement of the general welfare of the population, etc., will be achieved by this concept. From the aforesaid, it can be concluded that a number of interconnected and integrated benefits will be gained by full implementation of the new concept of karst water utilisation. The application of the concept designed in this way, ultimately implies the establishment of an integrated management of all karst water in the area of Zlatibor. In order to achieve this goal, it is necessary, primarily, to solve the problem of adequate public water supply by karstic groundwater, which implies the establishment of integrated karstic water management in this area, and that is the focus of this paper.

Keywords: Integrated water management, karst, water supply, Zlatibor

\section{Applied concept and methodology of research}

Sustainable management and usage of water resources in the $21^{\text {st }}$ century are an essential challenge that the humankind comes across. An accelerated industrial development, a rapid increase of the world population, an uneven distribution of natural resources in relation to the nations' material wealth, 
climate changes-those are only some of the causes which have led to the reduction of water resources' availability on the Earth to the level of grave concern.

This fact is equally reflected in both surface and groundwater resources (Glasser et al., 2007; UNEP 2012).

The principle of integrated water resources management (IWRM) is one of the manners and procedures deployed in an attempt to unifyingly manage the processes which promote and coordinate the development and management of water, ground/soil and relational resources (Global Water partnership, 2000). Although it was proposed seventy-odd years ago, the IWRM concept underwent a particular expansion and promotion in the 1990s and 2000s (Biswas, 2004). Although at first sight it may seem attractive, a more detailed analysis indicates its complicated applicability, especially from the hydrogeological aspect of research, management and exploitation of groundwater resources. This is emphasized by many leading hydrogeologists dealing with this subject matter. Foster (Foster and AitKadi, 2012), for instance, in his analysis, examines exactly the issues of the groundwater position in the IWRM concept and the relation of groundwater bodies with the main research unit in IWRM- which is a river basin. From this analysis, we may see that the systems of deep aquifers with a mainly karst or fractured aquifer type (particularly in the areas with occasional surface water flows) cannot be treated through universal concepts of water resources management with a significant reliability, but they demand special solutions. Morphologically speaking, this primarily refers to mountainous areas, whose specific features can hardly fit in with the flow charts of management in river basins. Viviroli et al., (2011) are just examining the relation between the research and management of mountain water resources from the stance of current climate changes. Groundwater resources in mountainous areas do not often occur within the same river basin as a main research unit, but they are characterized by some specific features which are manifested in the availability of water resources, endangered condition of water resources and the environment, unevenness related to population density, unevenness of economic activities and trends of tourism development, etc. In addition, an adaptive management approach

(Tujchneider et al., 2013) as well as climate changes aspects of influences on mountainous water management, also need to be examined in details (Theurillat and Guisam, 2001; Middelkoop et al. 2001).

This paper particularly examines the segment of groundwater management in mountainous karst areas, where specific characteristics of the research and management of karst water resources may be fully observed.

The Zlatibor mountain massif is situated in Western Serbia and it is the main tourist destination in the country. The ideal altitude (about 1000 a.s.l), extraordinary climatic conditions, as well as the abundance of beautiful scenery, geoheritage and bioheritage, have created preconditions for the stay of 250,000 guests on the mountain annually. This type of trend has caused the rapid urbanization of the area in the past decades. As a result, numerous challenges have arisen in the natural resource management as well as in the sustainable development of the area. Therefore, in the past few years, the authors of the paper have been engaged in a scientific project of integrated management and optimal utilisation of all natural resources in the Zlatibor mountain massif area. The trend of increase in the number of tourists has resulted in the increased demand for water amounts for water supply, which is currently mainly met by surface water from the Zlatibor reservoir with the capacity of $120 \mathrm{I} \mathrm{s}^{-1}$. Unlike quantitative characteristics, the quality of water in this reservoir is not at a satisfactory level, thus the raw water is submitted to the treatment in order to remove turbidity, iron, manganese, heavy metals, etc. (Milenic et al., 2011a). Additionally, the catchment of this reservoir spreading on about $60 \mathrm{~km}^{2}$ is highly vulnerable to the excessive pollution. Due to constant tourism growth and inadequately solved issue of water supply to the population, due to the construction of new infrastructure, the existence of environmental pollution hot spots, and the presence of significant potential of karstic groundwater resources, the establishment of integrated karstic water management (Fig. 1) has been imposed as the optimal solution. Its implementation would provide a basis for integrated karst water management in the Zlatibor mountain massif area. 


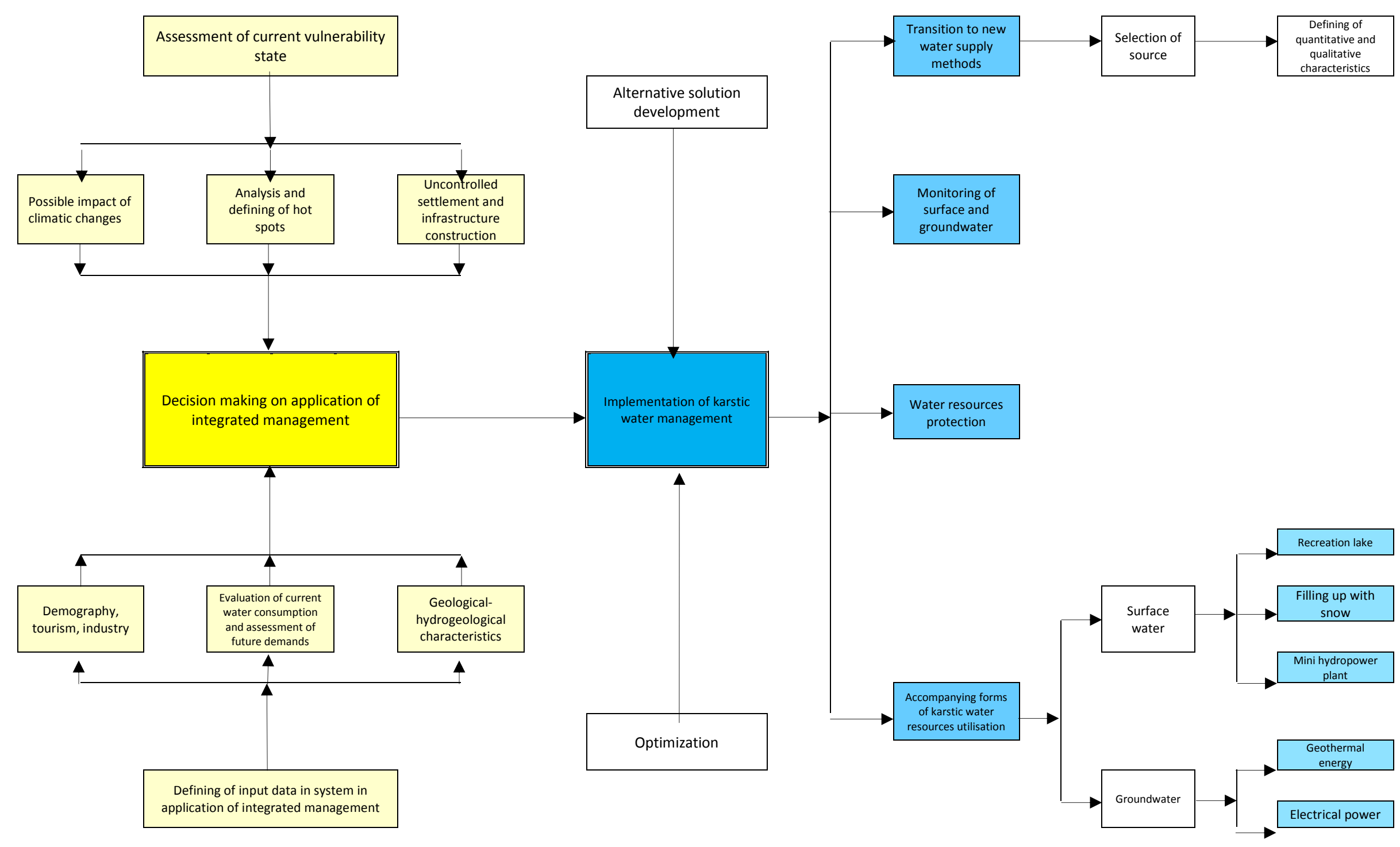

Figure 1. Applied concept and methodology of research 


\section{Decision making on the application of concept for integrated karstic water management}

Water resource management is a demanding and complex assignment. On one side, the needs of all potential users should be met, while on the other one, sustainable development must, certainly, be taken into account. In the first phase, the aim of the research was to define input data in the decision making system in the application of the concept for integrated karstic water management and to evaluate the current state of the environmental vulnerability in the study area. After the analysis was conducted, the decision was made on the application of the concept for integrated karstic water management in the Zlatibor mountain massif area.

\subsection{Defining of input data in decision making system}

\subsubsection{Trends of demographic, tourism and industrial development}

There are 21 settlements in the study area (Fig. 3a). Two settlements have urban characteristics (Cajetina and Zlatibor), while other settlements are rural. According to censuses from the year 1948 to the year 2011, the population decreased by a quarter (from 20,266 inhabitants in the year 1948 to 15,629 inhabitants in the year 2011). The increase in number of inhabitants was recorded in urban settlements, whereas in settlements situated in the northern part of the massif where agriculture is practised, namely food industry has developed.

The primary economic activity of inhabitants is tourism. Seasonal influx of tourists, besides positive (economic) impacts, also causes numerous adverse impacts on the environment, the most significant of them being:

- increased consumption of drinking water

- increased amount of waste water, and

- increased amounts of solid waste

Agriculture and food industry are most dominant of all industrial activities. Agricultural production is undergoing a decline, as a result of depopulation in rural areas, out-of-date technology for production, tiny holdings and the lack of irrigation systems which do not provide profitable farming culture. Unlike agricultural production, the food industry is on a constant increase. In addition to agriculture and the food industry, other branches, developed to a lesser extent, are textile industry, the industry of plastic processing, metal and wood processing.

Analyzing demographic, industrial and tourism trends (Fig. 3a) the following conclusions were drawn:

- Zlatibor mountain massif is characterized by uneven population density, the highest is in the north-eastern and central parts

- Generally, a steady population decline is recorded in this area, whereas the increasing trend in the number of people is recorded in the north-eastern and central parts, which coincides with the population density

- Industrial activity is declining, in terms of spatial distribution, it is mostly located in northern parts. This area is characterized by a significant number of tourists (about 250,000 annually), and a significant growth is recorded in this sphere

- Spatially observed, tourism is mostly developed in the area of the Zlatibor tourist settlement and the catchment area of the Zlatibor reservoir.

\subsubsection{Evaluation of current utilisation of water and assessment of future needs}

Surface water of the Zlatibor reservoir on the Crni Rzav River is used for the centralized water supply of the population of the largest settlements. Additionally, reservoirs were constructed on almost all other streams fringing the Zlatibor mountain massif (Vrutci on the Djetinja River, Svrackovo on the Veliki Rzav River) and are used for regional water supply. Excessive filling up of the reservoir bottom, the inability to implement adequately sanitary protection measures within separated zones, eutrophication of the lake, 
are just some of the reasons which led to the occurrence of a large number of algal accumulations in the Vrutci reservoir by the end of the year 2013, and this resulted in the exclusion of the water supply system for about 70,000 inhabitants who used the water from the mentioned reservoir. Such events have shown that the concept of water supply from surface water reservoirs is unreliable. In the past when these reservoirs were built, little attention was paid to the potential as well as to comparative advantages of the utilisation of karstic groundwater. Only in the eastern part, the Zmajevac springs are used for centralized water supply and for bottling. The total capacity of these springs is approximately $30 \mathrm{I} \mathrm{s}^{-1}$, which makes up less than $10 \%$ of the available amount of karstic groundwater in the periods of a hydrological minimum.

The current state of public water supply is characterized by the following features:

- mainly inadequately resolved issue of centralized water supply system especially in karst areas of the field (Fig. 3b), and permanent increase in the required amount of water for public water supply

- relatively poor quality characteristics and unstable regime of the surface water from the Zlatibor reservoir

- permanent increase of filling up and increased concentrations of heavy metals in the sludge at the bottom of the Zlatibor reservoir, and significant vulnerability to the pollution of its catchment

- threat to surface water quality and the environment downstream of the water treatment plant with the Zlatibor reservoir, owing to activities related to the treatment of raw water from the reservoir

- heightened seasonal imbalance in water consumption especially in the tourist resort of Zlatibor

In the future the increase in number of tourists will lead to the increase of required water amounts for public water supply. Taking into account the fact that the utilisation of surface water from the Zlatibor reservoir is not an adequate solution, there is a clear necessity for the change to a new concept of water supply. Based on the research carried out so far, for the optimal solution to the problem it is necessary to provide about $200 \mathrm{~s} \mathrm{~s}^{-1}$, which can be achieved by the utilisation of karstic groundwater.

\subsubsection{Geological and hydrogeological characteristics}

The Zlatibor mountain massif belongs to the area of the Inner Dinarides. It is mostly made of a carbonate rock complex of Middle and Upper Triassic age, and a diabase-chert formation and ultramaphites of Jurassic age. Paleozoic metamorphites are distributed in northern and north-eastern parts. Younger Cretaceous and Neogene sediments mainly overlie Mesozoic sediments transgressively.

A karst aquifer formed within carbonate sediments of Triassic age and a fractured aquifer formed within the ultramaphite rock complex are predominantly distributed in the Zlatibor area (Fig. 2).

The fractured aquifer is characterized by heterogeneity and anisotropy in terms of water-bearing capacity. There are several fractured zones, in which groundwater is accumulated, when drilling to the depth of up to $150 \mathrm{~m}$. Within this aquifer, there were formed groundwater reserves of a local character (Milenic et al., 2011b). The most significant groundwater reserves are accumulated within the karst aquifer which is recharged to the full extent on the account of infiltration of atmospheric precipitation (about 1,000 $\mathrm{mm}$ of water column per year), then on the account of the influx of water from the fractured aquifer with which it is in the hydraulic connection as well as on the account of the sinking of surface water streams. This aquifer is drained by a number of springs (Tab. 1, Fig. 2), which occur: at the contact of the Triassic limestone and the water-impermeable base, tectonic contacts of Triassic limestone with low water-permeability rocks, and at the contact of Triassic limestone with Neogene sediments along the margin of Neogene basins. Occurrences of subthermal water $\left(17-20^{\circ} \mathrm{C}\right)$ (Vapa Spa and Gostilje Spring) are indicative of the deep circulation of karstic groundwater. Based on the research carried out so far, it is estimated that the minimum yield of karst springs in the area of the Zlatibor mountain massif amounts about $300 \mathrm{I} \mathrm{s}^{-1}$, while the maximums go up to over $3,000 \mathrm{I} \mathrm{s}^{-1}$ (Tab. 1). 

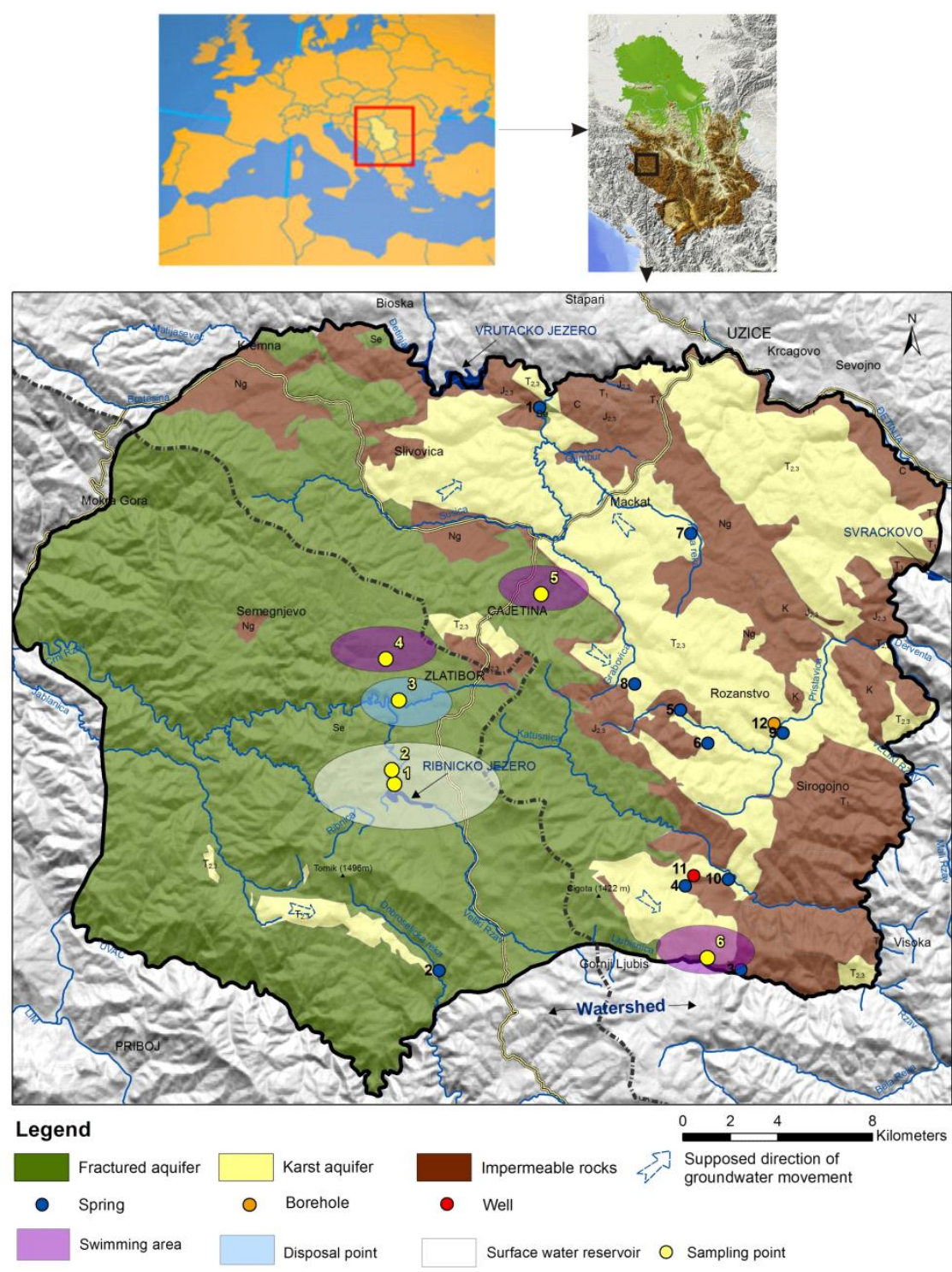

Figure 2. Schematized hydrogeological map of Zlatibor mountain massif

Karstic groundwater is characterized by low mineralization, a $\mathrm{HCO}_{3}{ }^{-}$class and a calcium, namely calciummagnesium group and a neutral to low alkaline reaction (Tab. 1). Increased concentrations of magnesium in some samples and a mildly alkaline reaction (Susicko Vrelo spring, Ljubisko Vrelo spring, Gostilje spring) point to the fact that the catchment areas of these springs are not constituted entirely of a carbonate rock complex. Concentrations of magnesium, reaching the value of $40 \%$ eq point to the hydraulic connection between karst aquifers and fractured aquifers formed within the ultramaphite rock complex. 
Table 1. Survey of karstic spring yield in area of Zlatibor mountain massif

\begin{tabular}{|c|c|c|c|c|c|c|c|c|c|c|c|c|}
\hline No. on Fig. 2 & 1 & 2 & 3 & 4 & 5 & 6 & 7 & 8 & 9 & 10 & 11 & 12 \\
\hline $\begin{array}{l}\text { Name of } \\
\text { occurrence }\end{array}$ & $\begin{array}{c}\text { Susicko Vrelo } \\
\text { Spring }\end{array}$ & $\begin{array}{l}\text { Dobroselicka } \\
\text { Vrela Springs }\end{array}$ & $\begin{array}{l}\text { Ljubisko } \\
\text { Vrelo } \\
\text { Spring }\end{array}$ & $\begin{array}{c}\text { Gostilje } \\
\text { Spring }\end{array}$ & Zmajevac & $\begin{array}{l}\text { Idjovo } \\
\text { Spring }\end{array}$ & Kotren & $\begin{array}{l}\text { Golovo } \\
\text { Spring }\end{array}$ & $\begin{array}{l}\text { Vapa } \\
\text { Spa }\end{array}$ & $\begin{array}{c}\text { Subthermal } \\
\text { Spring } \\
\text { Gostilje }\end{array}$ & $\begin{array}{l}\text { Zlatibor } \\
\text { voda }\end{array}$ & IBBV-1/10 \\
\hline $\begin{array}{l}\text { Type of } \\
\text { occurrence } \\
\text { /facility }\end{array}$ & $\begin{array}{l}\text { Desc. } \\
\text { spring }\end{array}$ & $\begin{array}{l}\text { Desc. } \\
\text { spring }\end{array}$ & $\begin{array}{l}\text { Desc. } \\
\text { spring }\end{array}$ & $\begin{array}{l}\text { Desc. } \\
\text { spring }\end{array}$ & $\begin{array}{l}\text { Desc. } \\
\text { spring }\end{array}$ & $\begin{array}{l}\text { Desc. } \\
\text { spring }\end{array}$ & $\begin{array}{l}\text { Desc. } \\
\text { spring }\end{array}$ & $\begin{array}{l}\text { Desc. } \\
\text { spring }\end{array}$ & $\begin{array}{l}\text { Asce. } \\
\text { spring }\end{array}$ & $\begin{array}{l}\text { Asce. } \\
\text { spring }\end{array}$ & Well & $\begin{array}{c}\text { Test } \\
\text { borehole }\end{array}$ \\
\hline$Q_{\min }\left(I s^{-1}\right)$ & 120 & 40 & 50 & 40 & 8 & 5 & 3 & 5 & 2 & 2 & 7 & - \\
\hline$Q_{\text {Mean }}\left(\mid \mathrm{s}^{-1}\right)$ & 640 & 60 & 120 & 100 & 53 & 10 & 10 & 15 & 2 & 2 & 7 & 10 \\
\hline$Q_{\max }\left(I s^{-1}\right)$ & 1650 & 300 & 350 & 626 & 95 & 30 & 22 & 50 & 2 & 2 & 7 & - \\
\hline $\begin{array}{l}\text { Current } \\
\text { purpose }\end{array}$ & - & - & $\begin{array}{c}\text { Fish } \\
\text { farming }\end{array}$ & - & $\begin{array}{l}\text { Water } \\
\text { supply }\end{array}$ & $\begin{array}{l}\text { Water } \\
\text { supply }\end{array}$ & - & - & - & - & Bottling & - \\
\hline $\mathrm{T}\left({ }^{\circ} \mathrm{C}\right)$ & $9-13$ & 10.1 & 9.3 & 10.2 & 10.2 & 9.5 & 10 & 9 & 17.5 & 17.5 & 15 & 16.5 \\
\hline$M\left(\left.m g\right|^{-1}\right)$ & 320 & 291 & 370 & 305 & 348 & 345 & 300 & 361 & 342 & 312 & 376 & 350 \\
\hline $\mathrm{pH}$ & 7.5 & 7.5 & 7.9 & 7.9 & 7.4 & 7.2 & 7.5 & 7.6 & 7.1 & 7.4 & 8.2 & 7.6 \\
\hline $\mathrm{HCO}_{3}^{-}\left(\mathrm{mg} \mathrm{l}^{-1}\right)$ & 348 & 298 & 264 & 353 & 365 & 374 & 287 & 378 & 379 & 332 & 250 & 280 \\
\hline $\mathrm{SO}_{4}^{2-}\left(\mathrm{mg} \mathrm{l}^{-1}\right)$ & 7 & 8 & 11 & 17 & 12 & 4 & 11 & 4 & 3 & 2 & 9 & 3 \\
\hline $\mathrm{Cl}^{-}\left(\mathrm{mg} \mathrm{l}^{-1}\right)$ & 8 & 24 & 5 & 1 & 21 & 20 & 4 & 33 & 20 & 18 & 10 & 5 \\
\hline $\mathrm{Na}^{+}\left(\mathrm{mg} \mathrm{l}^{-1}\right)$ & 5 & 15 & 3 & 5 & 6 & 14 & 3 & 22 & 10 & 19 & 5 & 10 \\
\hline $\mathrm{K}^{+}\left(\mathrm{mg} \mathrm{l}^{-1}\right)$ & 1 & N.D. & N.D. & 1 & N.D. & N.D. & 1 & N.D. & - & - & N.D. & - \\
\hline $\mathrm{Ca}^{2+}\left(\mathrm{mg} \mathrm{l}^{-1}\right)$ & 67 & 79 & 57 & 63 & 118 & 116 & 83 & 81 & 110 & 98 & 57 & 130 \\
\hline $\mathrm{Mg}^{2+}\left(\mathrm{mg} \mathrm{I}^{-1}\right)$ & 36 & 15 & 22 & 30 & 9 & 5 & 4 & 29 & 11 & 5 & 24 & 14 \\
\hline
\end{tabular}

Desc.- Descending; Asce.- Ascending; N.D.-no data 


\subsection{Assessment of current state of threat to environment}

\subsubsection{Analysis of possibility of climate change impacts on environment}

The study area is characterized by a moderate continental and mountain climate type, known for hot summers and cold winters with separate seasons. Based on the data of the National Hydrometeorological Institute, an analysis and comparison of the values of the two main climatic parameters, rainfall and temperature, was conducted in the Zlatibor area. The results of two statistical sequences of 30 years, from the year 1961 to the year 1990, and from the year 1981 to the year 2010, were analysed pointing to the fact that there are some changes that can affect the balance and the groundwater regime.The value of mean monthly rainfall per year increased from $964 \mathrm{~mm}$ to $1017 \mathrm{~mm}$, while the number of days with rainfall higher than $10 \mathrm{~mm}$ increased from 30 to 33 .

The climate changes of this kind certainly affect and will still affect the regime and quality of Zlatibor karstic water. More highlightedunevenness in the distribution of rainfall and an increase in mean annual air temperatures have already resulted in the fact that some karst springs have a lower yield, as well as in increases in the amplitude of fluctuation of maximum and minimum yield. The effective infiltration in karst areas is reduced, which results in an unbalanced temperature regime. This is especially the case with springs of the gravitational type in northeastern part of the Zlatibor massif. The stated data clearly point to the significance of this type of research in the phase of defining the degree of threat to the environment. The application of measures of the integrated karstic water management is just one of possible solutions in the regulation of the karst aquifer that is most affected by climate change in relation to other types of aquifers in the mountain massif of Zlatibor.

\subsubsection{Analysis and defining of hot spots of pollution}

In determining the need for the application of integrated karstic water management, it is extremely significant to determine the conditions and the level of threat to the environment. This is particularly significant with regard to frequent complaints of the population and tourists of the quality of drinking water in recent years. The lack of facilities for waste water processing, releasing of by-products from the reservoir after water treatment as well as the uncontrolled discharge of mine water to the surface streams, have resulted in the pollution of surface waters. For the purpose of the paper, six locations were determined (Tab. 2, Fig. 2) from which water samples were taken for a quality analysis. Additionally, reference literature data on the environmental quality in the Zlatibor area were collected.

Table 2. Quality of surface water

\begin{tabular}{|c|c|c|c|c|c|c|c|c|c|}
\hline \multirow[b]{2}{*}{ No } & \multirow[b]{2}{*}{ Name } & \multicolumn{8}{|c|}{ Parameter } \\
\hline & & $\mathrm{pH}$ & $\begin{array}{c}\text { Dry } \\
\text { remnant } \\
\left(\mathrm{mg} \mathrm{l}^{-1}\right)\end{array}$ & BPK & $\begin{array}{l}\text { Dissolved } \\
\mathrm{O}_{2}\left(\mathrm{mg} \mathrm{l}^{-1}\right)\end{array}$ & $\begin{array}{c}\text { Suspended } \\
\text { matters }\end{array}$ & $\begin{array}{c}\text { Aerobic } \\
\text { mesophilic } \\
\text { bacteria } \\
\end{array}$ & $\begin{array}{c}\text { Total } \\
\text { coliform } \\
\text { bacteria } \\
\end{array}$ & $\begin{array}{c}\text { Stream } \\
\text { class }\end{array}$ \\
\hline 1. & $\begin{array}{c}\text { Crni Rzav River } \\
\text { below } \\
\text { reservoir }\end{array}$ & 8.2 & 268 & 1.4 & 8.9 & 16 & 400 & 8800 & Ila \\
\hline 2. & $\begin{array}{c}\text { Crni Rzav River } \\
\text { downstream of } \\
\text { mine water } \\
\text { discharge }\end{array}$ & 8.2 & 329 & 3.8 & 6.7 & 14 & 100 & $<2000$ & Ila \\
\hline 3. & $\begin{array}{c}\text { Obudojevica } \\
\text { River after } \\
\text { discharge from } \\
\text { sewage }\end{array}$ & 7.8 & 268 & 4.5 & 5.0 & 18 & 300000 & $>240000$ & II b \\
\hline 4. & $\begin{array}{c}\text { Zlatibor Lake } \\
\text { Bathing }\end{array}$ & 7.9 & 177 & 1.9 & 8.8 & 6 & $<100$ & 24000 & 1 \\
\hline 5. & $\begin{array}{l}\text { Musvete } \\
\text { Bathing }\end{array}$ & 8.4 & 210 & 0.7 & 9.3 & 4 & 2000 & $<2000$ & I \\
\hline 6. & $\begin{array}{c}\text { Boskova Voda } \\
\text { Bathing }\end{array}$ & 7.8 & 190 & 1.8 & 6.9 & 3 & $<100$ & $<2000$ & 1 \\
\hline
\end{tabular}


On the basis of a comprehensive analysis, numerous pollution hot spots, namely the spots that must be included in the monitoring system through integrated management, were determined with reliability.

Additionally, the following conclusions were drawn:

- $\quad$ periodical air pollution controls have shown that there are slightly increased concentrations of nitrogen oxides and sulphur, soot and sediment matters during summer and winter, in relation to spring and autumn periods, which is related to the increased frequency of tourists and traffic during summer and winter tourist seasons

- Monitoring of the soil quality does not exist, while the monitoring of surface water is mainly related to the water quality in the Zlatibor reservoir used for public water supply

- Examinations of the groundwater quality in this area are considerably more frequent and more extensive (Tab. 1)

- The Zlatibor reservoir is, in addition to the unstable qualitative regime and relatively low water quality, threatened to be filled up by a deposit which in the year 2005 was at the level of 12.3\%, and that is $2.3 \%$ higher than usual capacities reserved for the deposit accumulation (Divac and Vuckovic, 2005)

- By the examinations of heavy metal content in sediments within the reservoir (Nikic and Mijovic, 2000) it was found that the concentrations of toxic elements $\mathrm{Ni}, \mathrm{Cd}, \mathrm{Hg}, \mathrm{Cr}$, and $\mathrm{Zn}$ are higher than the maximum allowed values, which is the result of geological structure of the catchment area and the interaction of the ultramaphite with the surface water and groundwater in the catchment area

- The plant for the treatment of water from the Zlatibor reservoir is situated next to the dam. Water treatment consists of clarification, filtration, disinfection, and stabilization. The following chemicals: aluminium sulphate, lime, active silicic acid and chlorine are used in water treatment. The above-mentioned chemicals, after the treatment of the raw water from the reservoir are discharged downstream of the reservoir into the river Crni Rzav, whereby they significantly affect the pollution of surface water courses

- In addition to the pollution caused by the treatment of the water from the reservoir, the river Rzav water is also polluted by mine water from the magnesite mine located downstream of the reservoir, as well as by sewage waste water which via the river Obudojevica runs into the Crni Rzav River downstream of the tourist settlement of Zlatibor (Tab.2)

2.2.3. Analysis of impact of uncontrolled construction of settlements and infrastructure on the environment

Numerous tourists in the study area have caused a distinguishedurbanization of the area in recent decades. The uncontrolled construction of settlements in parts of the terrain within the catchment area of the reservoir Zlatibor represents the major problem for water resources. An additional problem in these settlements is inadequately built infrastructure that did not follow the growth of settlements in the area. In the karst parts of the terrain, there are numerous settlements and roads, which pose a potential risk for the groundwater formed within the karst aquifer. Predisposed directions of karstification and a tectonic activity have pointed to a great risk of road network construction in some areas, bearing in mind significant cave systems and the possibility that construction work may suddenly open cave systems and thereby threaten groundwater and the environment as a whole.

\section{Implementation of karstic water management}

Based on the all-embracing analysis of the factors and components which have posed a threat to a sustainable usage and management of karstic water resources, the conclusion was drawn of the necessity of executing the measures of active management of karstic water resources. To this effect, 
firstly, an analysis of other variant solutions was carried out, and afterwards their optimization and immediate application. The results we have reached in Chapter 3 are presented in that particular order.

The development of variant solutions for integrated karstic water management comprises two levels. The first one deals with advantages and disadvantages of groundwater and surface water, where, after a comprehensive analysis, the decision was made to provide integrated water management. At the second level two variant solutions were also considered: the first was focused on the fractured aquifer, which has a significant distribution in this area, while the second one dealt with the analysis of groundwater resources related to the karst aquifer. Based on various criteria (demographic, industrial and tourism trends, solution of the centralized issue of water supply and distribution of the karstic aquifer type), the following conclusions were drawn (Fig. 3):

- Population density in non-karst areas of the terrain is considerably lower than in karst areas

- Migration occurs from non-karst to karst-areas, that is, taking into account the factor of altitudes, from the areas with higher altitudes to those characterized by lower altitudes

- Population increases in most settlements situated in karst areas, and decreases in settlements situated in non-karst areas

- It is indicative that despite the significant karst groundwater resources, the water supply issue in most cases is inadequately resolved in settlements located in karst areas of the terrain. The only example of good practice are settlements in eastern part in which karst water is used from the Zlatibor mountain massif, which solved the water supply problem by the utilisation of karstic groundwater

- Taking into account the indentation of settlements and economic factors of the unique water system construction, as well as the disproportion in water amounts required for the water supply of some settlements, what appears to be the optimal solution is the opening of several water supply systems by karstic groundwater, and this would adequately resolve the issue of water supply.

The need and justification to develop the concept of integrated karstic water management can be clearly perceived since the current state indicates the disproportion between the potentials of water resources and the degree of utilisation. In addition, the implementation of the mentioned concept will create preconditions for integrated management of all (ground and surface) water resources in the area of the Zlatibor massif.

Integrated karstic water management implies the centralization of decision-making to a large extent. In this way the possibility of the conflict of interests of individual users is reduced and a higher degree of synchronization is provided (Stevanovic, 2011). Karstic parts of the terrain, which are the topic of this paper, are mainly distributed within the Morava catchment (Fig. 3c) where they are uncovered in about $40 \%$ of the surface, while in the area of the Drina catchment (west parts of terrain), the fractured aquifer formed within ultramaphite rock complex is predominantly distributed. All analysed karst hydrogeological phenomena and facilities except the Dobroselicka Vrela Springs are located within the Morava catchment, and therefore integrated karstic water management in the study area will be mainly focused on the Morava catchment.

\subsection{Change to new way of water supply}

\subsubsection{Selection of karstic springs for water supply of settlements}

Significant untapped reserves of karstic groundwater, and their relatively high quantitative properties and stable qualitative regime, have conditioned the new concept of public water supply. The basic idea of integrated karstic water management is to open several new karstic springs for public water supply due to natural features of the terrain and dispersion of settlements (Fig. 4). The selection was made based on the following criteria: 

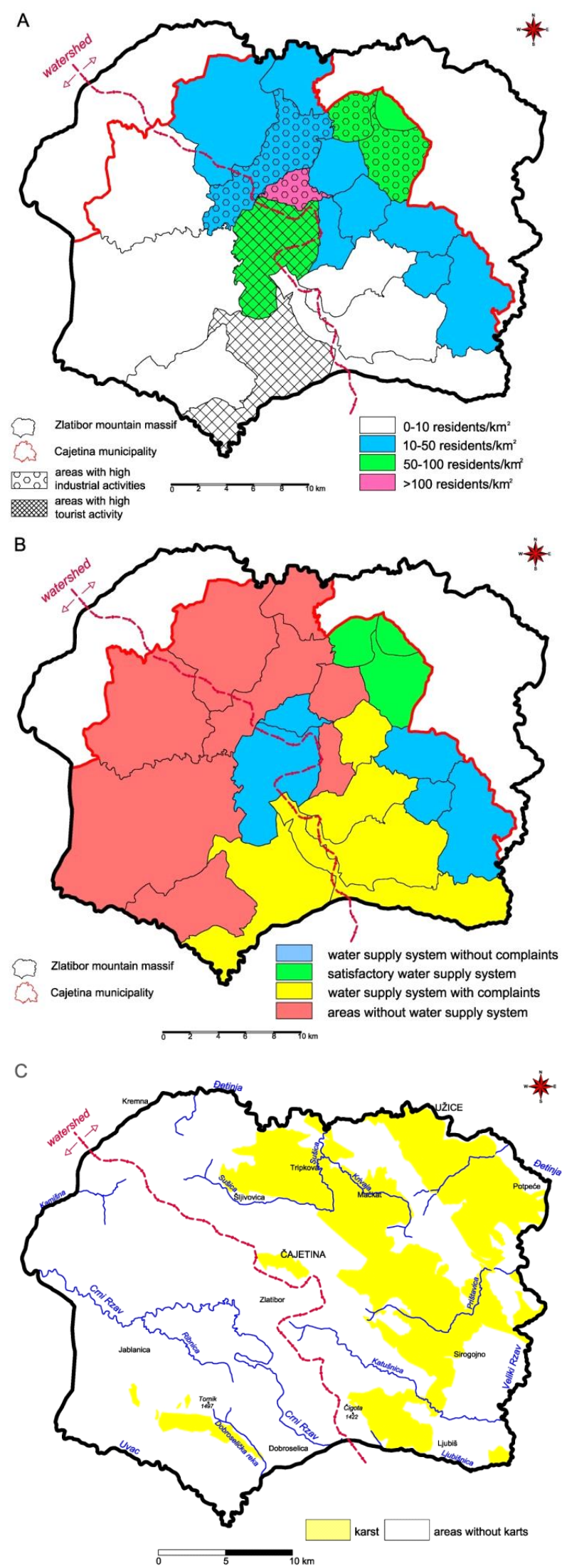

Figure 3. Comparative analysis of analysed criteria in concept of integrated karstic water management 


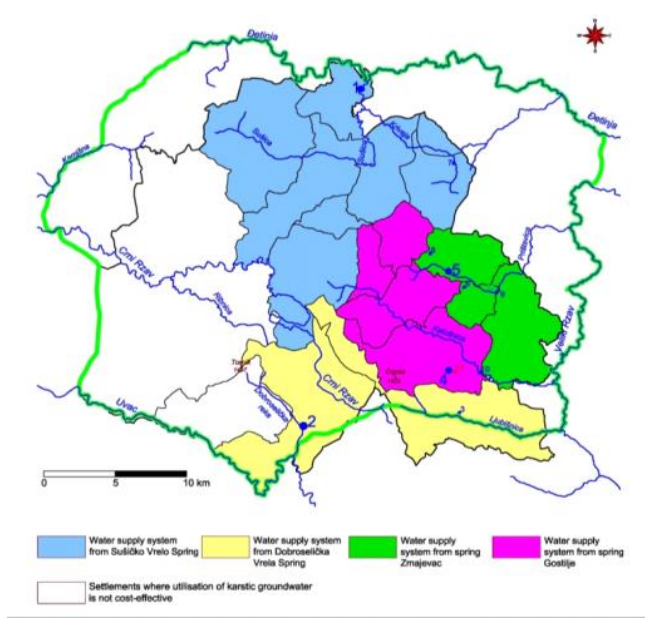

Figure 4. Preliminary design of public water supply by karstic groundwater

- $\quad$ spring capacity (minimum, medium, maximum)

- qualitative properties of groundwater

- groundwater regime

- distance of a source from potential users

- assessment of vulnerability to pollution and conditions for protection of karstic groundwater

- economic cost-efficiency project realisation

3.1.2. Defining quantitative and qualitative characteristics of karstic groundwater (Case Study-Susicko Vrelo Spring)

Geological and hydrogeological characteristics of the Susicko Vrelo Spring catchment area caused the complexity of groundwater and surface water balance in the area, which is characterized by the presence of an open hydrogeological structure and a medium degree of karstification $\left(Q_{\min }: Q_{\max }=1: 13.75,4\right.$ karstic occurrences $\left./ \mathrm{km}^{2},=0.02\right)$. Out of the total catchment area (approximately $168 \mathrm{~km}^{2}$ ) parts of the karst terrain occupy almost a half (approximately $82 \mathrm{~km}^{2}$ ), while the rest of the catchment area spreads across parts of the non-karst terrain (ultramaphites, diabase-chert formation, neogene sediments.). The Susicko Vrelo Spring catchment area consists of autogenic part of the catchment from where water directly infiltrates into the karst aquifer, as well as of allogeneic part of the catchment where surface streams sink diffusely when entering the karstified parts of the catchment (Fig. 5).

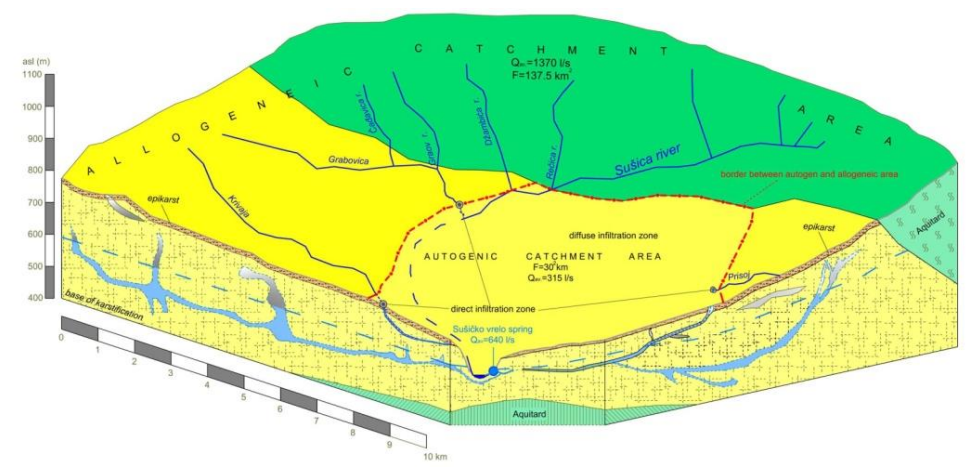

Figure 5. Schematized survey of Susicko Vrelo Spring catchment area

Fig. 6 shows a comparative diagram of precipitation and yield of the Susicko Vrelo Spring for the period from $1^{\text {st }}$ September 2011 to $31^{\text {st }}$ October 2012, and here we can see that these two parameters are in the functional dependence. 


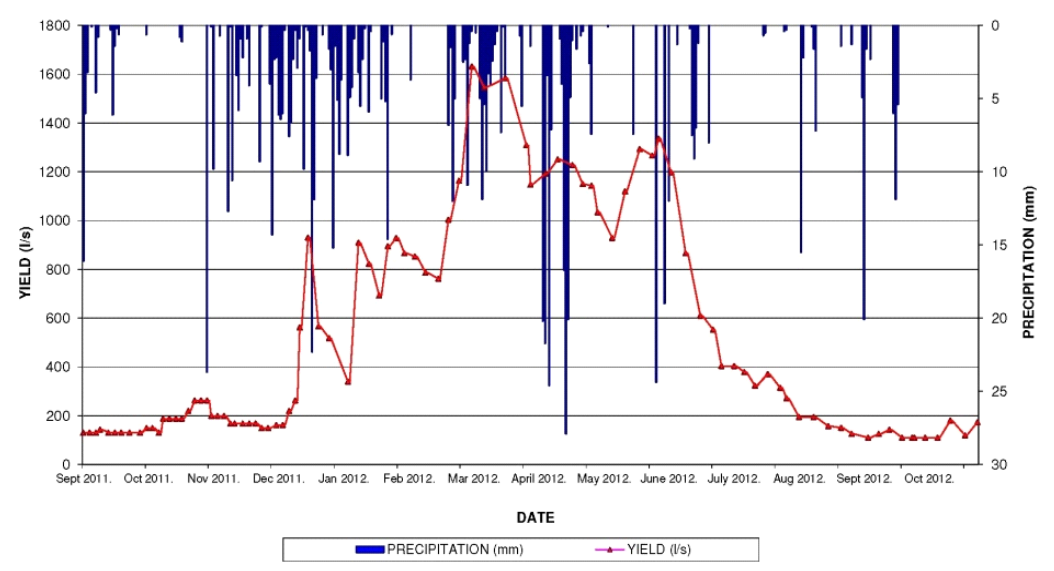

Figure 6. Comparative diagram of precipitation $(\mathrm{mm})$ and yield of Susicko Vrelo Spring for the period 1st September 2011 to 31st October 2012

The groundwater of Susicko karst spring is characterized by low mineralization (TDS $<500 \mathrm{mg} \mathrm{I}^{-1}$ ), neutral to mildly alkaline reaction and hydrocarbonate-calcium-magnesium type. Monitoring qualitative groundwater regime of Susicko karst spring, it has been confirmed that this spring is characterized by a relatively stable qualitative regime.

\subsection{Other aspects of water resource utilisation}

\subsubsection{Surface water}

Space for the new purposes of the areas near the Zlatibor reservoir will be made by the change to water supply of the settlements of Cajetina and Zlatibor by groundwater from the Susicko Vrelo Spring. Producing documents on spatial planning, this area will be transformed into a new sports and recreation zone, which will improve the tourist offer of this mountain resort. There is also a plan to use the water from this reservoir for artificial snowing up of ski slopes in the nearby ski resort, while in summer, the reservoir is supposed to provide for activities such as sailing, fishing and swimming. Due to favourable morphological conditions of the Zlatibor reservoir catchment area, the opening of a golf course is planned in its immediate vicinity. In addition to the improvement of the tourism offer, positive effects that will follow by the change of the use of space surrounding the Zlatibor reservoir, will also include the facilitation of other economic activities, which were limited to the establishment of sanitary protection zones at the catchment area of the reservoir.

\subsubsection{Groundwater}

In addition to water supply, karst groundwater can be used for ancillary purposes, primarily as a source of hydrogeothermal energy and a resource to generate electricity. Multiple benefits could be achieved by this approach to the utilisation of karstic groundwater resources. Methodologically speaking, the approach implies the cascade utilisation of karstic groundwater, thus it is possible, simultaneously, to meet needs for water supply, heating or cooling facilities and, partly, needs for electrical power. The functioning of multi-purpose systems requires a multidisciplinary approach in designing, with the ultimate aim of achieving the maximum energy "efficiency" of groundwater resource. This practically means that thermotechnical substations with heat-pumps, and a microturbine system can be built in the pipeline route, according to the characteristics of a terrain, and consumers' needs. The energy benefits can also be achieved by the installation of specialized water pipes with built-in turbines to generate electrical power. Schematically, an energy-efficient route consists of four points: a pipeline begins from the point of groundwater source, comes to the point where its temperature falls by means of a heat exchanger (amounts remain unchanged), then there comes the point of a micro-turbine plant which uses the kinetic energy of water to generate electricity and continues towards a plant for water treatment for public water supply. (Fig. 7). The condition for the functioning of energy efficient routes is 
the configuration of the field, namely the route designed in the way in which the movement of groundwater occurs by free fall.

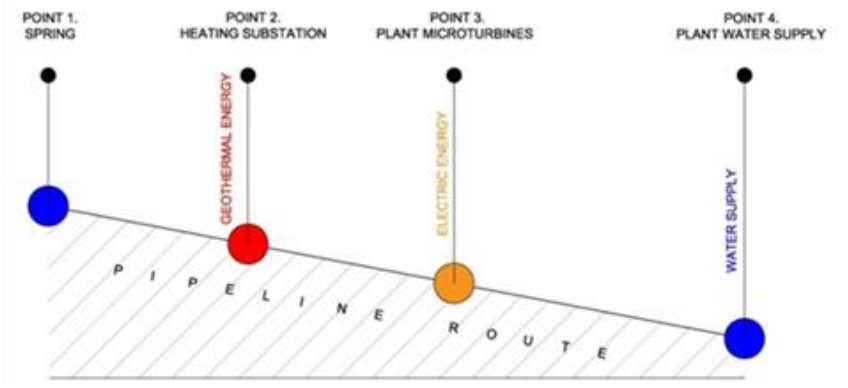

Figure 7. Schematic view of energy-efficient groundwater route

\subsection{Protection of water resources and environment}

Significant environmental benefits will be achieved by the concept of integrated karstic water management in the area of Zlatibor massif, and they will be seen in the following:

- reduction of water pollution of the Crni Rzav river caused by discharging of by-products of water treatment from the Zlatibor reservoir

- improvement of the conditions of groundwater protection by the establishment of sanitary protection zones around new water supply sources

- protection of the environment from the adverse effects of droughts and floods

- improvement of general health of the population using water of a sufficient quality and stable regime

- reduction of greenhouse gas emission into the atmosphere by the utilisation of hydrogeothermal energy for heating of buildings

\section{Conclusions}

The principle of sustainable development is closely connected with the integrated management of the environment, that is water resources management as its inextricable part. The setting-up of integrated karstic water management may often represent the basis for further expansion of the overall system of the environment management. Specific features of mountainous tourist resorts that were examined in this paper served as the basis for the development of methodology for establishing the integrated management of karst water resources. Apart from the grade of the karst water resources, the work also presents possibilities of their multi-purpose cascade use.

The Zlatibor mountain massif is the leading tourist destination in Serbia. In recent decades significant changes have occurred as regards demography, tourism and infrastructure, which has led to the necessity to establish a new concept of water resources and the environmental management on the whole. The old approach to water resources management did not follow the changes caused by the construction of new infrastructure, which created numerous problems. The public water supply is mostly at an unsatisfactory level. In addition, the current water supply system of central settlements has led to the formation of hot spots of surface water and the environmental pollution which have successively increased over time. The existence of considerable karstic groundwater reserves of a good quality, established the precondition for the change to the new concept of public water supply, which implies the establishment of integrated karstic water management in this area. It is envisaged to solve the public water supply by using groundwater from several karstic springs that meet quantitative and qualitative criteria related to the water supply branch. In addition, the multi-purpose utilisation of the water is envisaged, such as: a geothermal resource and a resource to generate electrical power. Numerous accompanying benefits primarily reflected in the improvement of surface water quality and 
the environment on the whole, would be achieved by integrated karstic water management. This approach would create space for the water from surface reservoirs, that is currently being used for water supply, to change the purpose, i.e. to be utilised for snowing up of ski slopes during winter seasons, and for the rest of the year for fishing, sailing and swimming, which is in accordance with the development prospects of the region. The establishment of integrated karstic water management in the area of Zlatibor massif, is the foundation of the integrated management of all water resources (groundwater and surface water) and the environment on the whole.

\section{ACKNOWLEDGMENT}

This paper is conducted within the Ministry of Education, Science and Technological Development of the Republic of Serbia-Research and Development Renewable Groundwater Resources in the Concept of Enhancing Energy Efficiency in Buildings (TR 33053).

\section{REFERENCES}

Biswas A. (2004), Integrated water resources management: A reassessment a water forum contribution, Water International, 29, 248-256.

Divac D. and Vuckovic D. (2005), Maintenance, management and monitoring of eight large dams-part I analysis of constructed dams and reservoirs (Zlatibor on Crni Rzav), Report, Institute for the development of water resources "Jaroslav Cerni", Belgrade (In Serbian).

Foster S. and Ait-Kadi M. (2012), Integrated Water Resources Management (IWRM): How does groundwater fit in?, Hydrogeology Journal, 20, 415-418.

Glasser S., Gauthier-Warinner J., Gurrieri J., Keely J., Tucci P., Summers P., Wireman M. and McCormack K. (2007), FS-881-Technical Guide to Managing Groundwater Resources, U.S. Forest Service, U.S. Geological Survey, Bureau of Land Management and U.S. Environmental Protection Agency, pp.1-281.

Global Water Partnership (2000), Integrated water resource management, TAC Background papers No.4, Stockholm: GWP Secretariat.

Middelkoop H., Daamen K., Gellens D., Grabs W., Kwadijk J.C.J., Lang H., Parmet B.W.A.H., Schädler B., Schulla J., Wilke K. (2001), Impact of climate change on hydrological regimes and water resources management in the Rhine basin, Climatic Change, 49, 105-128.

Milenic D., Milankovic Dj., Vranjes A. and Prohaska S. (2011a), Definition of sanitary protection zones on the reservoir "Zlatibor" in Ribnica, Proceedings of the XI International conference "Water and sewage systems", pp. 69-76, Jahorina.

Milenic D., Milankovic Dj. and Vranjes A. (2011b), Possibility of bottling groundwaters from ultramafic Zlatibor massif, Association for water technology and sanitary engineering, 41, 33-46.

Nikic Z. and Mijovic D. (2000), The role of the geological environment in the formation of the chemical composition of the sludge in surface accumulation "Zlatibor" on the river Rzav, Nature protection, 52, 143-149 (in Serbian).

Stevanovic Z. (2011), Management of groundwater resources, Faculty of Mining and Geology, Belgrade .

Theurillat J.P. and Guisam A. (2001), Potential impact of climate change on vegetation in the european alps: a review, Climatic Change, 50, 77-109.

Tujchneider O., Christelis G. and Gun J.V.D. (2013), Towards scientific and methodological innovation in transboundary aquifer resource management, Environmental Development, 7, 6-16.

UNEP (2012), The UN-Water Status Report on the Application of Integrated Approaches to Water Resources Management, UN Water Report, pp.1-106.

Viviroli D., Archer D.R., Buytaert W., Fowler H.J., Greenwood G.B., Hamlet A.F., Huang Y., Koboltschnig G., Litaor M.I., Lopez-Moreno J.I., Lorentz S., Schadler B., Schreier B., Schwaiger K.,Vuille M. and Woods R. (2011), Climate change and mountain water resources: overview and recommendations for research, management and policy, Hydrology and Earth System Sciences, 15, 471-504. 